\section{Frost Tolerance of Eight Olive Cultivars}

\author{
Diego Barranco and Natividad Ruiz \\ Departamento de Agronomía, Universidad de Córdoba, ETSIAM, P.O. Box \\ 3048, 14080 Córdoba, Spain

\section{María Gómez-del Campo \\ Departamento de Producción Vegetal-Fitotecnia, Universidad Politécnica de Madrid, 28040 Madrid, Spain}

Additional index word. electrolyte leakage, electrical conductivity, lethal temperature, $\mathrm{LT}_{50}$, Olea europaea

\begin{abstract}
This study aims to determine the relationship between laboratory frost-resistance data for the leaves of eight olive cultivars and observed field resistance in the same genotypes undergoing natural frost damage. The lethal freezing temperature $\left(\mathrm{LT}_{50}\right)$ for each cultivar was established by measuring the electrical conductivity (EC) of the medium into which solutes from damaged leaf tissue were leaked. The value obtained was then correlated with percentage frost shoot for the same eight cultivars damaged by natural frosts in a field test. A negative correlation was observed between the percentage frost shoot and leaf $\mathbf{L T}_{50}$ for all the cultivars under study. The most frost-hardy cultivars ('Cornicabra', 'Arbequina', and 'Picual') were those presenting the lowest percentage frost shoot and lowest $\mathbf{L T}_{50}{ }^{\circ}$ Conversely, the most frost-susceptible cultivar ('Empeltre') displayed $100 \%$ frost shoot, together with one of the highest $\mathrm{LT}_{50}$ values $\left(-9.5^{\circ} \mathrm{C}\right)$. According to these results, lethal freezing temperature $\left(\mathbf{L T}_{50}\right)$ calculated from leaf ion leakage at a range of freezing temperatures, seem to be a valid parameter for evaluating frost tolerance in olive cultivars.
\end{abstract}

The olive is an evergreen plant grown mainly in the Mediterranean basin. Olive growth and productivity are limited by low temperatures in winter and frost damage in spring and fall.

Although the olive is moderately resistant to subzero temperatures, below a certain resistance threshold freezing temperatures can damage the plant; damage to aerial parts of the plant at below $-7^{\circ} \mathrm{C}$ can reduce productivity (Palliotti and Bongi, 1996), while at $-12{ }^{\circ} \mathrm{C}$ damage may be serious enough to threaten the life of the tree (Larcher, 1970). Frost conditions occur quite frequently in Italy and Spain, but also in some southern zones of Europe and America (Denney et al., 1993). The most characteristic symptoms of frost damage include tip burn of shoots tips and nearby leaf tips, leaf chlorosis, defoliation, bark split on branches and also damages to buds and fruits.

Cultivation techniques such as irrigation, reduction in nitrogen fertilizer rates, late pruning and bare-soil maintenance systems, have been widely used in commercial orchards to limit frost damage. However, the most effective way to combat damage, apart from simply avoiding frost-prone areas, is to use cold-hardy planting material. Selection of the least susceptible varieties is the most effective indirect method of avoiding frost damage.

A number of surveys and field trials following natural frosts have provided frost-tolerance data for several olive varieties (Antognozzi and Catalano, 1985; Barranco, 2004; Barranco et

Received for publication 13 July 2004. Accepted for publication 18 Sept. 2004. We are thankful to the World Olive Germplasm Bank of Córdoba, CIFA "Alameda del Obispo", IFAPA, Córdoba, and the ITDA of the Comunidad de madrid, Spain for their suport. This work was funded by the project CAO 00-011-C12 of the Junta de Andalucía. Spain. al., 2000; Fiorino and Mancuso, 2000a; Fontanazza and Preziosi, 1969; Pezzarossa, 1985). However, most of these studies have been based on isolated and somewhat subjective observations in areas with differing frost intensity, which has led to contradictory findings.

Laboratory methods hitherto used to discriminate between frost-resistant and frost-sensitive genotypes have been based on: measurement of electrical resistance (Mancuso, 2000); differential thermal analysis, reflecting the presence or absence of exotherms (Bartolozzi and Fontanazza, 1999; Fiorino and Mancuso, 2000b); vital stain (Fiorino and Mancuso, 2000b); release of phenolic compounds (Roselli et al., 1992); leaf tissue browning (Roselli et al., 1992); plant recovery capacity (Bartolozzi and Fontanazza, 1999; Bartolozzi et al., 2002); and electrolyte leakage (Bartolozzi and Fontanazza, 1999; Fiorino and Mancuso, 2000b; La Porta et al., 1994; Roselli et al., 1992). Such methods have not always been effective, and even successful methods tend to be costly and/or laborious.

Frost affects plant cell membranes, which become less permeable and even break, giving rise to the leakage of solute from damaged cells; this electrolyte leakage can be measured in terms of the electrical conductivity (EC) of the medium (Lindén and Palonen, 2000). EC measurement is a simple, quick, effective and reproducible way of selecting olive genotypes by cold hardiness. However, to our knowledge, none of the studies published up to date have compared the results obtained using this method with field observation of whole plants. This study aims to determine the relationship between laboratory frost-resistance data for the leaves of eight olive cultivars and observed field resistance in the same genotypes undergoing natural frost damage.
Field tests. Olive plants roughly $80 \mathrm{~cm}$ high, vegetatively propagated from semi-harwood cuttings, were planted in April 2001 at the Olive-growing Center of the Instituto Tecnológico de Desarrollo Agrario (ITDA) in Madrid, Spain $\left(40^{\circ} 04^{\prime} \mathrm{N}, 03^{\circ} 31^{\prime} \mathrm{W}\right)$. The following cultivars were planted: 'Arbequina', 'Cornicabra', 'Frantoio', 'Hojiblanca', 'Nevadillo de Jaén', 'Picual', 'Empeltre', and 'Manzanilla Cacereña'. The eight cultivars were planted in a randomize complete block design with 20 blocks, with one tree as experimental unit. The plot was affected by two frosts, one reaching $-6.5{ }^{\circ} \mathrm{C}$ (11 Nov. 2001) and the other -10.5 ${ }^{\circ} \mathrm{C}$ (16 Dec. 2001). Frost damage to aerial parts of each plant were evaluated in May 2002. Following removal of the whole aerial portion, dry matter was quantified separately for frost shoots and undamaged shoots after oven-drying at $80{ }^{\circ} \mathrm{C}$, and the percentage of frost shoots per plant was calculated.

Laboratory tests. In January 2003, leaves from the same eight cultivars were collected from the CIFA Olive Germoplasm Bank in Córdoba, Spain. Sample leaves were in all cases completely expanded, and were taken from the middle portion of the year's shoots, from north-facing parts of the tree.

Discs, $7 \mathrm{~mm}$ in diameter, containing the central vein, were punched from each leaf and placed in test tubes (10 discs per tube). Tubes were then closed and placed in a wire mesh which was then inserted in a HAAKE F3 refrigerating bath containing a 1:3 mixture of ethylene glycol and water, thus preventing freezing of the medium in which the tubes were immersed. Tubes were exposed for 1 $\mathrm{h}$ to a range of temperatures between $-2{ }^{\circ} \mathrm{C}$ and $-20^{\circ} \mathrm{C}$ (9 freezing temperatures). Two replications were performed per cultivar and temperature. After one hour, replications for the first temperature were removed, and the refrigerating bath was reset to the next lower temperature, and so forth, at intervals of $2{ }^{\circ} \mathrm{C} / \mathrm{h}$ (Bartolozzi and Fontanazza, 1999).

Tubes removed from the refrigerating bath were placed in a refrigerator $\left(4^{\circ} \mathrm{C}\right)$ for $1 \mathrm{~h}$, after which $8 \mathrm{~mL}$ deionized water was added to each tube. Tubes were then shaken for 24 h using a Heidalph Unimax 1010 shaker at $120 \mathrm{rpm}$ in light conditions, at an ambient temperature of 20 to $22^{\circ} \mathrm{C}$. The initial electrolytic conductivity of each solution (initial $\mathrm{EC}$, in $\mu \mathrm{S} \cdot \mathrm{cm}^{-1}$ ) was measured using a Crison 524 conductivity meter, to obtain an indirect indication of the amount of ions released at each freezing temperature.

Sample tubes were then autoclaved $(1 \mathrm{~h}$, $120{ }^{\circ} \mathrm{C}, 1 \mathrm{~atm}$.) to kill the tissues completely (Bartolozzi and Fontanazza, 1999; Fiorino and Mancuso, 2000b). After $2 \mathrm{~h}$ shaking at $200 \mathrm{rpm}$ in light conditions, electrical conductivity was measured again (autoclave EC), to obtain a reference value for total ions. Relative EC at each temperature $(\mathrm{T})$ was calculated as $\mathrm{ECr}=$ (initial EC/autoclave EC) $\times 100$.

Statistical analysis. The relationship between ECr (ion leakage at each temperature as a percentage of total ions) and temperature 
(T) was described by a sigmoid curve, which was fitted using the following logistical function (Fiorino and Mancuso, 2000b; Palliotti and Bongi, 1996): $\operatorname{ECr}(\%)=\left[\mathrm{a} / 1+\mathrm{e}^{\mathrm{b}(\mathrm{T}-\mathrm{c})}\right]+$ $\mathrm{d}$, where $\mathrm{ECr}=$ relative electrical conductivity (initial EC/autoclave CE) $\times 100 ; \mathrm{T}=$ absolute value of treatment temperatures $\left({ }^{\circ} \mathrm{C}\right) ; \mathrm{a}=$ range of $\mathrm{ECr}$ from minimum to maximum temperatures tested; $b=$ slope coefficient ( $a t$ the temperature of the inflection point); $\mathrm{c}=$ temperature at the inflection point $\left(\mathrm{LT}_{50}\right) ; \mathrm{d}$ $=$ minimum value of ECr. Parameters were estimated using the curve fitting on non-linear regression methods of the statistical software package SPSS for Windows, version 8.0 (SPSS, 1994).

The inflection point of the sigmoid curve (parameter c) predicts the lethal freezing temperature $\left(\mathrm{LT}_{50}\right)$ and corresponds to the subzero temperature at which $50 \%$ ion leakage occurs, a point reported to correspond to irreversible lethal damage (Boorse et al., 1998; Levitt, 1980; Li, 1984; Lindén and Palonen, 2000; Palliotti and Bongi, 1996).

The inflection point c on the curve and the percentage shoot frost were subjected to analysis of variance, and 5\% least significant differences were used to segregate differences among treatment means using Duncan's multiple range test. The statistical software used was MSTAT-C (University of Michigan).

The coefficient of correlation between percentage frost shoot and $\mathrm{LT}_{50}$ was determined.

\section{Results and Discussion}

Changes in relative electrical conductivity (ECr) for the eight cultivars studied ('Arbequina', 'Cornicabra', 'Frantoio', 'Hojiblanca', 'Nevadillo de Jaén', 'Picual', 'Empeltre', and 'Manzanilla Cácereña') are shown in Fig. 1. In all cases, ECr was described by a sigmoid curve whose inflection point predicts the lethal freezing temperature $\left(\mathrm{LT}_{50}\right)$.

Table 1 shows frost shoot dry matter as a percentage of total aerial dry matter, together with $\mathrm{LT}_{50}$ values for all eight cultivars. The lowest percentage shoot frost was recorded for 'Cornicabra' (44.5\%), followed by 'Arbequina' (62.6\%). The most frost-sensitive cultivar was 'Empeltre' $(100 \%$ shoots damaged), followed by 'Frantoio'(94.7\%), 'Hojiblanca'(89.2\%) and finally 'Manzanilla Cacereña' $(83.8 \%)$. The lowest $\mathrm{LT}_{50}$ values (i.e. the greatest frost hardiness) were observed for 'Cornicabra' $\left(-13.3^{\circ} \mathrm{C}\right)$ and 'Picual' $\left(-13.2{ }^{\circ} \mathrm{C}\right)$, followed by 'Arbequina' $\left(-11,8{ }^{\circ} \mathrm{C}\right)$. The highest value for $\mathrm{LT}_{5}$ was that of 'Manzanilla Cacereña', which displayed a statistically-significant difference with respect to the three cultivars

Fig. 1. Relative electrical conductivity (ECr) for eight olive cultivars at different freezing temperatures. with the lowest $\mathrm{LT}_{50}$, indicating a high degree of frost-susceptibility.

A significant negative correlation ( $r=$ $-0.81^{*}$ ) was observed for all eight cultivars between percentage frost shoot and leaf $\mathrm{LT}_{50}$. The most frost-hardy cultivars ('Cornicabra', 'Arbequina', and 'Picual'), were those which displayed the lowest percentage frost shoot and the lowest $\mathrm{LT}_{50}$. Conversely, the most frost-susceptible cultivar ('Empeltre') displayed 100\% frost shoot, together with one of the highest $\mathrm{LT}_{50}$ values $\left(-9.5^{\circ} \mathrm{C}\right)$. These results agree with earlier findings for these cultivars in prospecting surveys and field trials after natural frosts
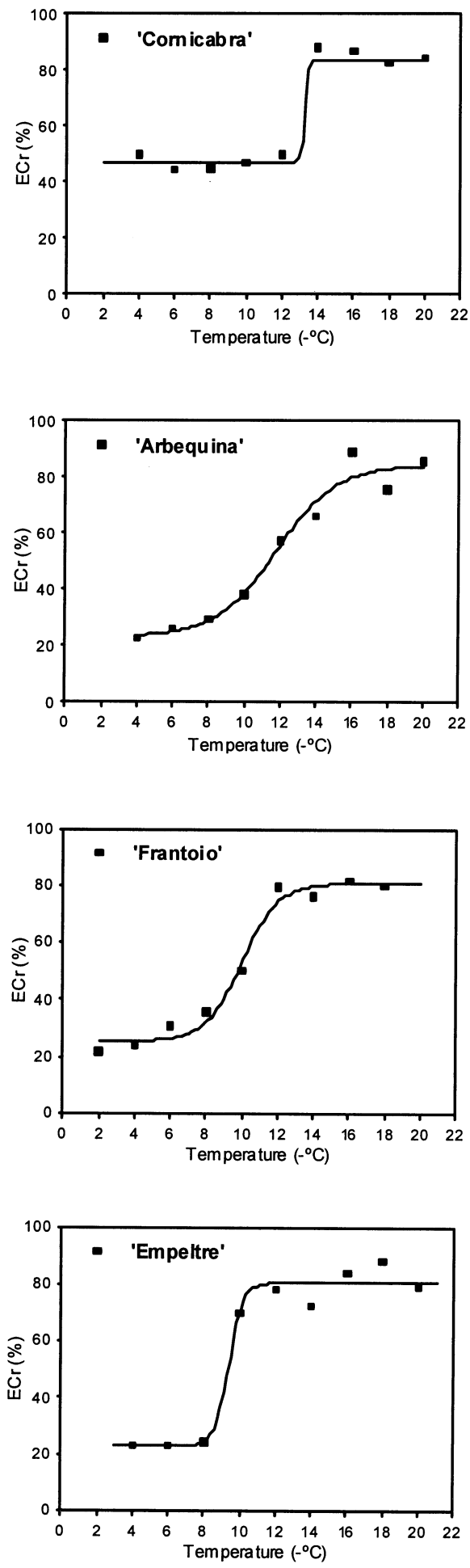

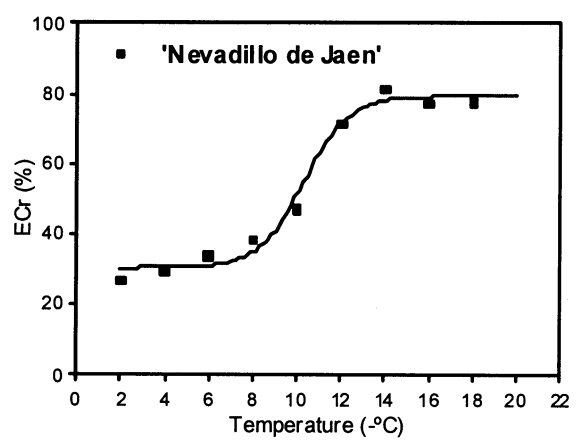

(Barranco, 2004; Barranco et al., 2000).

'Hojiblanca' is generally considered cold-hardy (Barranco et al., 2000; Barranco, 2004), and in the present study was classed in the intermediate-resistance group together with 'Frantoio'. To illustrate the disparity of the results reported by other authors in field studies, 'Frantoio' has been classed as resistant (Pezzarossa, 1985), susceptible (Antognozzi and Catalano, 1985; Tombesi, 1986; Barranco et al., 2000) or intermediate (Fontanazza and Preziosi, 1969; Fiorino and Mancuso 2000a). Studies in controlled conditions using the methods applied here (ECr) found that 'Fran-
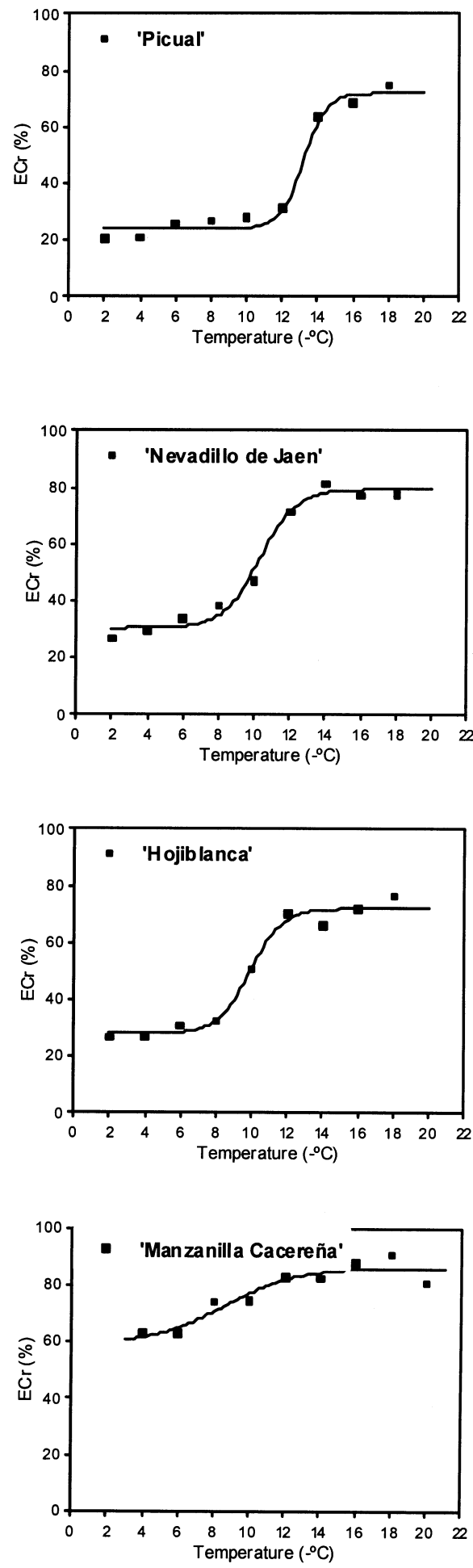
Table 1.Percentage frost shoot and leaf lethal freezing temperature $\left(\mathrm{LT}_{50}\right)$ in eight olive cultivars.

\begin{tabular}{lcc}
\hline & $\begin{array}{c}\text { Frost } \\
\text { shoot } \\
(\%)\end{array}$ & $\begin{array}{c}\mathrm{LT}_{50} \\
\left(-{ }^{\circ} \mathrm{C}\right)\end{array}$ \\
Cultivar & $44.5 \mathrm{e}^{\mathrm{z}}$ & $13.3 \mathrm{a}$ \\
Cornicabra & $71.0 \mathrm{~cd}$ & $13.2 \mathrm{a}$ \\
Picual & $62.6 \mathrm{de}$ & $11.8 \mathrm{ab}$ \\
Arbequina & $75.4 \mathrm{bcd}$ & $10.3 \mathrm{bc}$ \\
Nevadillo de Jaén & $94.7 \mathrm{ab}$ & $10.0 \mathrm{bc}$ \\
Frantoio & $89.2 \mathrm{abc}$ & $9.9 \mathrm{bc}$ \\
Hojiblanca & $100.0 \mathrm{a}$ & $9.5 \mathrm{bc}$ \\
Empeltre & $83.8 \mathrm{abcd}$ & $8.6 \mathrm{c}$ \\
\hline Manzanilla Cacereña &
\end{tabular}

${ }^{z}$ Within a column, means followed by different letters indicate significant differences between cultivars $(P$ $<0.05)$. Mean separation by Duncan's multiple range test at $P=0.05$.

toio' did not stand out as particularly resistant or particularly susceptible, and tended to be classed as "poorly-differentiated" (Bartolozzi and Fontanazza, 1999; Fiorino and Mancuso, 2000b).

According to these results, lethal freezing temperature $\left(\mathrm{LT}_{50}\right)$ calculated from leaf ion leakage at a range of freezing temperatures, would seem to be a valid parameter for evaluating frost tolerance in olive cultivars.

\section{Literatured Cited}

Antognozzi, E. and F. Catalano. 1985. Risposta varietale dell'olivo ai danni da freddo. Annali della Facoltà di Agraria, Universitá di Perugia 39:185-198.
Barranco, D. 2004. Variedades y patrones. In: D. Barranco, R. Fernández Escobar, and L. Rallo. El cultivo del olivo. Editorial Mundi-Prensa y Junta de Andalucía, Madrid, Spain.

Barranco, D., A. Cimato, P. Fiorino, L. Rallo, A. Touzani, C. Castañeda, F. Serafín, and I. Trujillo. 2000. Catálogo Mundial de Variedades de Olivo. Consejo Oleícola Intl., Madrid, Spain.

Bartolozzi, F., F. Cerquaglia, L. Coppari, and G. Fontanazza. 2002. Frost tolerance induced by cold acclimation in olive (Olea Europaea L.). Acta Hort. 586:473-475.

Bartolozzi, F. and G. Fontanazza. 1999. Assessment of frost tolerance in olive (Olea europaea L.). Scientia Hort. 81(3):309-319.

Boorse, G.C., T.L. Bosma, A.C. Meyer, F.W. Ewers, and S.D. Davis. 1998. Comparative methods of estimating freezing temperatures and freezing injury in leaves of chaparral shrubs. Intl. J. Plant Sci. 159(3):513-521.

Denney, J.O., D.O. Ketchie, J.W. Osgood, G.C. Martin, J.H. Connell, G.S. Sibbett, R. Kammereck, W.H. Krueger, and G.A. Nour. 1993. Freeze damage and coldhardiness in olive: Findings from the 1990 freeze. California Agr. 47(1)Spec. Sect:1-12.

Fiorino, P. and S. Mancuso. 2000a. Olivo e basse temperature: danni da freddo, adattamento e resistenza. L'Informatore Agrario 22:55-59.

Fiorino, P. and S. Mancuso. 2000b. Differential thermal analysis, supercooling and cell viability in organs of Olea europaea at subzero temperatures. Adv. Hort. Sci. 14:23-27.

Fontanazza, G. and P. Preziosi. 1969. L'Olivo e le basse temperature. Osservazioni su 37 cultivar da olio e 20 cultivar da mensa. L'Italia Agrícola, 78:737-745.
La Porta, N., M. Zacchini, S. Bartolini, R. Viti and G. Roselli. 1994. The frost hardiness of some clones of olive cv. Leccino. J. Hort. Sci. 69(3):433-435.

Larcher, W. 1970. Kakteresistenz und uberwinterungsvermogen mediterraner Holzpflanzer. Oecol. Plant. 5:267-286.

Levitt, J. 1980. Responses of plants to environmental stresses. vol. 1. Academic Press, New York

Li, P.H. 1984. Subzero temperature stress physiology of herbaceous plants. Hort. Rev. 6:373-415.

Lindén, L. and P. Palonen. 2000. Relating freezeinduced electrolyte leakage measurements to lethal temperature in red raspberry. J. Amer. Soc. Hort. Sci. 125(4):429-435.

Mancuso, S. 2000. Electrical resistance changes during exposure to low temperature measure chilling and freezing tolerance in olive tree (Olea europaea L.) plants. Plant Cell Environ. 23:291-299.

Palliotti, A. and G. Bongi. 1996. Freezing injury in the olive leaf and effects of mefluidide treatment. J. Hort. Sci. 71(1):57-63.

Pezzarossa B. 1985. Danni da freddo all'olivo nei vivai del pesciantino. Rivista di Frutticoltura 8:68-70.

Roselli, G., N. La Porta, and D. Morelli. 1992. Valutazioni del germoplasma di olivo per la tolleranza a stress da freddo. Atti Convegno Germoplasma Frutticolo. p. 107-112. Alghero, Italia.

SPSS 1994. SPSS advanced statistics. M. Norusis (ed.). SPSS Inc., Chicago.

Tombesi, A. 1986. Modalità di ristrutturazione degli olivi danneggiati dal gelo. Rivista di Frutticoltura 8:27-35. 